\title{
Bright spots, physical activity investments that work: the Finnish Schools on the Move programme
}

\author{
Antti Blom, ${ }^{1,2}$ Tuija Tammelin, ${ }^{2}$ Kaarlo Laine, ${ }^{2}$ Hannu Tolonen ${ }^{3}$
}

\section{BACKGROUND AND DESCRIPTION OF THE PROGRAMME}

The school setting is an essential domain in which to promote physical activity (PA), especially among the least active children who may benefit the most from it. In addition to well-recognised health benefits, PA has positive effects on children's cognitive function and scholastic performance. ${ }^{1}$ Considering that most children do not meet current PA recommendations, ${ }^{2}$ school-based PA promotions that deliver both health and academic benefits are essential to education.

Finnish Schools on the Move (FSM) (figure 1) is a national action programme to establish a physically active operating culture in schools. ${ }^{3}$ Schools and municipalities participating in FSM implement their own plans to enhance PA during the school day, mostly during recess and academic lessons (see box for some examples and see online supplementary video). Mandatory physical education lessons have not been increased on a large scale. Implementation of customised plans to promote PA has appeared to enhance principals', teachers' and students' feelings of ownership over the process. The programme supports the dissemination of the ideas and practises developed by schools through organising seminars and producing and distributing educational materials. FSM operates in close interaction with the central government and has been implemented from the bottom-up and top-down simultaneously.

FSM is funded by the Ministry of Education and Culture and coordinated by the Finnish National Agency for Education, regional state administrative agencies and various other organisations. In 2010, a 2-year pilot involving 45 schools throughout Finland was

${ }^{1}$ Finnish Schools on the Move-program, Finnish National Agency for Education, Helsinki, Finland

${ }^{2}$ LIKES Research Centre for Physical Activity and Health, Jyväskylä, Finland

${ }^{3}$ Ministry of Education and Culture, Helsinki, Finland

Correspondence to Antti Blom, Finnish National Agency for Education, Helsinki 00531, Finland; antti.blom@oph.fi launched. ${ }^{3}$ In the second phase (20122015), the programme was expanded significantly. In 2010, FSM initially focused on basic education (grades 1-9) and, since 2015, has also been implemented in upper secondary school and higher education. In the third phase (2015-2018), FSM has become a priority government programme regarding know-how and education. ${ }^{4}$ Its most recent goal is stated in the government's May 2015 strategic Finnish Schools on the Move (FSM) programme: 'The Schools on the Move project will be expanded across the country to ensure school children one hour of PA each day'. ${ }^{4}$ In January 2017, 77\% (1878 of 2449) of

\section{WHY IT WORKS?}

To support schools actions, €21 million have been allocated by the Ministry of Education and Culture to FSM to operate in municipalities for 2016-2018. Continuous evaluation is at the core of FSM. To support schools in implementing their action plans, FSM developed a self-evaluation tool for PA promotion in schools.

\section{Programme Card}

- Country/locality: Finland—Europe.

- Target population: whole basic education in Finland, 7 to 16 year olds (550 200 grade 1 to 9 students in Finland), comprehensive schools (2449).

- The aim of the programme is to establish a physically active operating culture in schools by promoting physical activity and decreasing excessive sitting especially during recess time and academic lessons.

- Which of the seven best investments the programme addresses?

- Finnish Schools on the Move (FSM) addresses all the seven best investments: (1) whole-of-school approach to support structured and unstructured physical activities throughout the day, (2) transport and the environment; active transport to school, (3) urban design and infrastructure; support for the development of school yards and facilities to enable physical activity, (4) healthcare and health education; training for school healthcare personnel on physical activity, fitness and wellbeing, (5) communication and public education including use of mass and social media, (6) whole-of-community approach involving key settings such as cities and municipalities, local governments and schools and (7) sports and recreation; collaboration with the National Olympic Committee, sporting organizations and community-based clubs and other sports providers to promote sports for all.

- What sectors it involves:

- Various collaborators are involved in the programme network, including the Ministry of Education and Culture, Finnish National Agency for Education, communities, schools and several different non-governmental organisations, among others.

- Estimated programme reach

- FSM will reach approximately almost $90 \%$ of Finnish elementary schools and $95 \%$ of pupils.

- What is unique about this programme?

- In Finland, the Finnish Schools on the Move programme has created new administrative and functional approaches to physical activity promotion and has successfully linked the goals of various collaborators into a shared network.

- Key contact(s): Antti Blom, antti.blom@oph.fi.

- Programme website: https://liikkuvakoulu.fi/. 

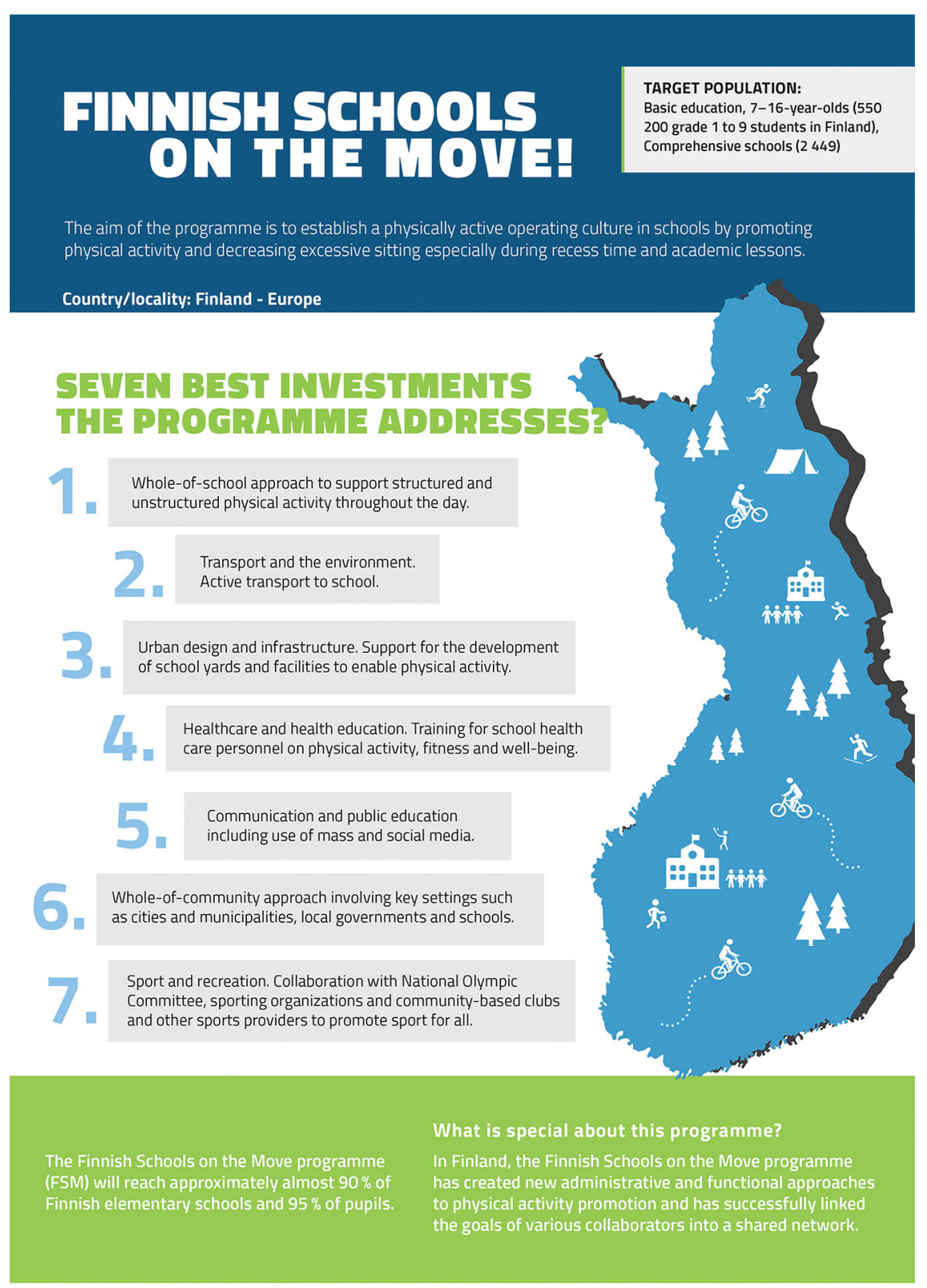

Box Examples of actions conducted

in schools to create a more physically active school day (see more details in Haapala et al. $\left.{ }^{6}\right)$

Organised physical activities (PAs) in the school setting

- Longer recess period to enable PA

- Organised recess activities

- Clubs and activities after school

- Physically active breaks during academic lessons

- Events related to sports and PA for whole school

- Equipment and facilities for PA

- Outdoor and indoor equipment available

- Development of sports facilities

- Involvement of the students

- Students participate in the school PA working group

- Students act as peer instructors and recess PA activators

- Educating the students on PA and instructing

- Leadership and school staff engagement related to the project

- Principal's support

- Hired project worker

- Educating the staff on PA

- Staff working group for PA promotion

- Communication and cooperation related to the project

- Informing and communication within the school

- Co-operation with parents, municipality and with local sports clubs

Other actions

- Students' PA monitoring

Figure 2 Graphic programme card of best investments.

Using this tool can increase schools' awareness of their status and plan their future actions. The tool also systemically collects data from schools to inform decision-makers about the programme's development. In December 2016, more than 1000 schools used the tool and completed an online survey.

Scientific research related to the programme and practical monitoring of the success of local projects have been conducted at different levels. Research has increased information on students' PA during the school day, ${ }^{5} 6$ PA and learning, ${ }^{7}$ psychosocial environment and social relationships at school, ${ }^{8}$ as well as the challenges and strengths of the FSM operations at different levels. This information has been used in developing the programme further. The research has been led by an academic centre ${ }^{3}$ and funded by the Ministry of Education and Culture.

Research has shown positive changes in FSM schools: increased PA during recess and throughout the school day, more recess time spent outdoors, more active commuting to school during winter and greater student involvement in the planning of school activities. ${ }^{356}$ Most respondents to the school staff surveys agreed that PA during the school day increases student satisfaction with school and contributes to a more peaceful learning environment during academic lessons. ${ }^{8}$

\section{LESSONS LEARNT}

Popular reporting of the research results in various media has been an essential part of the programme's communication and dissemination efforts. In the future (2016-2018), follow-up to the FSM programme will be integrated into the current national level monitoring of children and adolescents.

Tight connection between school administrators and local schools in all the administration involving them has been essential.

Certain features and elements of schoolbased PA promotion can be translated well from one country to another. However, to ensure the feasibility and success of operations at the school level, such programmes 
should be tailored to the unique culture and special features of the national educational system and policy.

Twitter twitter.com/liikkuvakoulu

Contributors $A B$ is the programme director of the Finnish Schools on the Move programme. TT is the research director of the LIKES Research Centre for Physical Activity and Health. KL is the unit director of the LINET research unit at LIKES. HT is the senior advisor of the Ministry of Education and Culture, Department for Youth and Sport Policy (chairman of a steering group for FSM for many years).

Competing interests None declared.

Ethics approval The study protocol was approved by the Ethics Committee of the University of Jyväskylä.

Provenance and peer review Commissioned; externally peer reviewed.

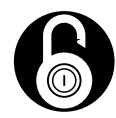

\section{OPEN ACCESS}

Open Access This is an Open Access article distributed in accordance with the Creative Commons Attribution
Non Commercial (CC BY-NC 4.0) license, which permits others to distribute, remix, adapt, build upon this work non-commercially, and license their derivative works on different terms, provided the original work is properly cited and the use is non-commercial. See: http:// creativecommons.org/licenses/by-nc/4.0/

(C) Article author(s) (or their employer(s) unless otherwise stated in the text of the article) 2018. All rights reserved. No commercial use is permitted unless otherwise expressly granted.

- Additional material is published online only. To view, please visit the journal online (http://dx.doi.org/ 10.1136/bjsports-2017-097711).

\section{D) Check for updates}

To cite Blom A, Tammelin T, Laine $\mathrm{K}$, et al. Br J Sports Med 2018;52:820-822.

Accepted 31 August 2017

Published Online First 27 September 2017

Br J Sports Med 2018;52:820-822. doi:10.1136/bjsports-2017-097711

\section{REFERENCES}

1 Donnelly JE, Hillman CH, Castelli D, et al. Physical activity, fitness, cognitive function, and academic achievement in children. Med Sci Sports Exerc 2016;6:1197-222.

2 Ekelund U, Tomkinson G, Armstrong N. What proportion of youth are physically active? Measurement issues, levels and recent time trends. $\mathrm{Br} J$ Sports Med 2011;45:859-65.

3 Tammelin T, Laine K, Turpeinen S. Report in Finnish, abstract in English. http://www.liikkuvakoulu.fi/sites/ default/files/liikkuvakoulu_loppuraportti_web.pdf

4 Prime Minister's Office, Finland. Finland, a land of solutions. Government publications. 2015. http://vnk.fi/ en/publication?pubid $=6407$

5 Haapala HL, Hirvensalo MH, Kulmala J, et al. Changes in physical activity and sedentary time in the Finnish Schools on the Move program: a quasi-experimental study. Scand I Med Sci Sports 2016;27. Epub ahead of print.

6 Haapala HL, Hirvensalo MH, Laine K, et al. Adolescents' physical activity at recess and actions to promote a physically active school day in four Finnish schools. Health Educ Res 2014;5:840-52.

7 Syväoja H, Kantomaa M, Laine K, et al. Physical activity and learning. Summary. Status review. Helsinki, Finland: National Board of Education, 2012. http://www.oph.fi/ download/145366_Physical_activity_and_learning.pdf

8 Kämppi K, Asanti R, Hirvensalo M, et al. Report in Finnish, abstract in English. http://www.liikkuvakoulu.fi/sites/ default/files/viihtyvyytta_ja_tyorauhaa_nettiversio.pdf 